\title{
Social Control on Postgraduate Students’ Deviant Behaviour
}

\author{
$1^{\text {st }}$ Ibrahim \\ Departemen of Social Education \\ Faculty of Social Science \\ Universitas Negeri Makassar \\ Makassar, Indonesia \\ ibrahim7105@unm.ac.id
}

\begin{abstract}
Social control is a concept as well as an institution that is almost always present and needed in every institution and social structure that exist in society. Prodi PIPS as a sub-institution / institution under the Faculty of Social Sciences Makassar State University also directly or indirectly activities and the actual process of social control undoubtedly its existence. The purpose of this study are: To determine the form of Social Control of deviant behavior of Social Science Education Studies Program Faculty of Social Sciences Makassar State University, this character is a qualitative research with phenomenology approach. The data collection techniques are: interview, observation, documentation. Data analysis of this research is done by categorization. The results showed that every human potential to perform deviant behavior is no exception students. Preventive and repressive social control are two forms of collective-functional control which means all elements / societies of PIPS Prodi based on their function. They have social control over student deviant behavior. The collective-functional control of the PIPS Prodi community is not yet maximized, yet consistently integratedcontinuously. If all elements of the Prodi PIPS community that is the lecturers, data pengimput and leadership Prodi involved in controlling behavior deviant students will be controlled from deviant behavior.
\end{abstract}

Keywords - Social Control, Deviant Behavior, Student

\section{INTRODUCTION}

The 1945 Constitution of the Republic of Indonesia mandates the Government to seek and administer a national education system that enhances faith, devotion to God Almighty, and noble character in the framework of educating the nation's life and advancing science and technology by upholding the values. religious values and national unity for the advancement of civilization and the welfare of mankind; that higher education as part of the national education system has a strategic role in educating the life of the nation and advancing science and technology by paying attention to and applying the values of the humanities and the sustainable cultivation and empowerment of the Indonesian people;

In connection with this noble task, the role of Lecturers and students is very urgent. Especially with students certainly have a strategic role to realize this noble task. this is confirmed that:

(1) Students as members of the Academic Community are positioned as adults who have their own awareness in developing their own potential in Higher Education to become intellectuals, scientists, practitioners, and / or professionals. (2) Students as referred to in paragraph (1) actively develop their potential by conducting learning,

\author{
$2^{\text {nd }}$ Hasni \\ Departement of Social Science Education \\ Faculty of Social Science \\ Universitas Negeri Makassar \\ Makassar, Indonesia \\ hasni@unm.ac.id
}

searching for scientific truths, and / or mastering, developing, and practicing a branch of Science and / or Technology to become scientists, intellectuals, practitioners, and / or cultured professionals. (3) Students have academic freedom by prioritizing noble reasoning and character and are responsible according to academic culture. (4) Students are entitled to get Education services according to their talents, interests, potential, and abilities. (5) Students can complete the Education program in accordance with their respective learning speeds and not exceed the time limit set by the University. (6) Students are obliged to maintain ethics and adhere to the norms of Higher Education to ensure the implementation of Tridharma and the development of academic culture. [1]

If listened to the message conveyed by Article 13 of Law No. 0. 12 of 2012, students should have maximum awareness in the lecture process. All potential and opportunities in college should be maximized. [2]-[4] This is important because students are positioned by Law No. 0.12 of 2012 as a human being or human being who has arrived at the level of maturity in terms of growth and physical and spiritual development. Decisions for lectures should be accompanied by full awareness of responsibility to keep abiding by all the values, norms and ethics of the recovery where he studied. But in fact there are still many students who have deviant behavior from campus culture that should be lived, followed and obeyed.

Students as human beings / individuals with a singular nature according to K.J. Veeger; "Repeatedly we have termed the importance of a human view that does not divorce social behavior from the core of the human personality, namely; awareness and freedom. ... at least we all recognize that humans who are not alienated from themselves, feel themselves free and powerful in themselves. Self awareness as an individual is closely related to existential freedom. If if he acts the same as many other people, he realizes the possibility of acting differently or not acting the same is decided by himself or at any time can be decided by himself. [5]-[7]

Based on K.J Veeger, it can be understood that students as human beings who have a singular nature also have the possibility of two things being actualized in their lives, namely their awareness and freedom specifically related to aspects of their behavior. On the one hand, students have the potential to have the awareness of obeying, following and obeying all academic rules, including ethics during college. But on the other hand students also have the potential to deviate from academic rules and ethics and values that are considered appropriate in the lecture process so that they are 
called deviant behavior. The thing that cannot be denied from the two possibilities of the student in the process of his journey to take lectures includes students of the Social Sciences Education Study Program ((Study Program. PIPS)

With regard to social control of students' deviant behavior that must be addressed, sociology has its own concept. One of them is what is suspected by Shari'ati. Shari'ati practiced sociology of praxis. He finds sociological laws from the field, then he propagates continuously until he creates the desired change. He said; "What is the use of a sociologist, if he is unable to tell us how to shape our society? How he helped the community and mastered social problems, if he limited himself to a position at the university, taught, and analyzed sociology by being confined to the walls of his classroom. Such sociologists will only be agents of authority. [8], [9]

From the illustration presented by Ali Shari'ati, if it is associated with social control, it is very relevant and responsive, especially related to the duties and role of Prodi lecturers. PIPS in responding to the deviant behavior of its students. As humans, students have the opportunity to conduct deviant behavior. Things that might be different are determinant factors that encourage the occurrence of deviant behavior among students. Each student must have his own case with regard to adherence and adherence to social values and social norms in the respective study program environment. Likewise, the case with Study Program students. PIPS ..

Social control is a concept and institution that is almost always there and is needed in every institution and social structure in society. [10]-[12] PIPS Study Program as a subinstitution / institution under the Faculty of Social Sciences of Makassar State University also directly or indirectly activities and the process of social control is in fact undoubtedly its existence. But what is it like and how does social control exist, this is something that must be known scientifically. At least related to the process of social control, the picture, form of persuasive social control and coercive determinants of student deviant behavioral factors as a central concept. Another thing is that the existence of a process of social control over deviant behavior of PIPS Study Program students has not yet been scientifically known. This is important because the deviant behavior of students cannot be allowed to have social control that can guarantee the noble goal of students to achieve their dreams or dreams in the future. As stated in article 13 of Law No. 12 of 2012.

\section{RESEARCH METHODS}

This type of qualitative research using a phenomenological approach. The main instrument of this study is researchers. Data collection method used technique; Interview, Observation, Documentation. checking the validity of the data with Observational Persistence, Triangulation, and Detailed Description. Data analysis is done by categorization.

\section{RESULTS AND DISCUSSION}

Deviant behavior is one of the many behaviors that can be carried out by humans in community life. As the main object in the study, humans have a multi-vision side in view of their existence. Every human being as a member of society to do deviations. The potential for deviant behavior in humans is certainly determined by many things. How complete human behavior is towards shared awareness with norms, norms, values upheld jointly with full obedience will determine human behavior.

Every human being is actually very necessary and will make a need for order (need order), but on the other hand humans also have rights and obligations based on the responses that occur with their environment, including the order itself. Humans in social life need rules, norms and values. The existence of rules, norms and values in living together is a necessity. Rules, norms and values that are the basis for maintaining harmony in the community. the selfish nature of man and all the bad temper of his individual tends to see himself as the owner of the truth that must be approved by others directly. If doing wrong or not knowing is the responsibility. How to make humans with themselves which then brings broad consequences in living together. Shared life within the community's rights and obligations are shared needs. If we discuss our rights effectively then there are no obligations that must also be fulfilled efficiently. In living together there will be no change when every member of society only aggressively demands their rights but is negligent in fulfilling their social obligations. These social obligations are obedience and obedience to mutual agreement on the rules, norms and values themselves.

The mirror of mankind in living together are agreed rules, norms and values. As long as the agreed rules are adhered to and followed, the authority of living in the community will be well organized. Mutual respect among community members will be carried out in the midst of the lives of its members. Shared ideals as a very strong foundation in society will provide momentum where each member will always be aware and eager to make it happen. In all things that happen, elements and parts in society for all will be needed in every action and responsibility of the community

Specifically, a smaller scope of life for the PIPS Study Program, as a result of consensus / collective agreement at the PIPS Study Program level, the rules, norms and values must be a guarantee of togetherness in order. Every person in the PIPS Study Program community whether it is the study program leader, lecturers, honorary and students absolutely make the rules, norms and values become academic references that must be adhered to and carried out responsibly. Advancing the community life PIPS study program was determined by all members of the PIPS Study Program community itself in implementing and internalizing the rules, norms and values in all their academic activities.

Ideally rules, norms and values are made for the common good. It is difficult to realize the collective order of academic processes when there are no rules that are understood and adhered to by the PIPS Study Program community. This condition can enable every member of the PIPS Study Program community to claim the truth unilaterally. If this is the case, it is impossible for the vision, mission and purpose of the existence of the PIPS Study Program to be realized.

In this part of the study, it will specifically describe one party / member of the PIPS Study Program community from students. The focus is more specific to aspects of student deviant behavior. To describe a fair and balanced manner 
regarding deviant behavior, PIPS Study Program students must of course have clear and clear parameters / indicators. This is done to avoid unilateral claims of truth, especially researchers who are also part of the PIPS Study Program community in this case as lecturers. In connection with this matter, the reference is the Decree of the Chancellor of Makassar State University Number; 2363 / UN36 / HK / 2017 concerning the Academic Regulations of Makassar State University and the Decision of the Chancellor of Makassar State University Number: 1406 / UN36 / KM / 2017 concerning Student Affairs of Makassar State University. reference to measure the deviant behavior of PIPS Study Program students. That is, whether the behavior of the PIPS Study Program students includes deviant behavior or no reference is the rule and the prevailing ethics in the UNM Makassar campus.

In general in the sociological perspective that the occurrence of a social fact and social situation is not without cause. There is always a cause or cause so something that happens is no exception to deviant behavior. The occurrence of a deviation in a society is a clue or a sign that within the community has experienced the following things. [13]

- The rules are incomplete or have been left behind in the development needs of the community.

- There are unclear rules of formulation, which lead to various kinds of interpretation and application.

- There are congestion in the implementation of bureaucracy.

- Distribution agencies are required for more community activities.

- The level of obedience decreased so that it is necessary to examine the causes.

- The degree of community unity has declined somewhat.

It shows the relevance to the emergence of student deviant behavior. Meanwhile, another similar opinion is expressed by David Lockwood that every social situation always contains in him two things, namely; normative social order, and sub-stratum that gave rise to conflicts. Order and conflict are two facts that stick together in every social system. The emergence of social order or value system agreed upon by members of the community, in no way implies the disappearance of conflict within society. On the contrary, the growth of social order reflects a potential conflict within every society. Therefore, when we talk about the stability and instability of a social system, we mean that it is really nothing more than to state the degree of success or failure of a normative order in in regulating conflicting interests. [14]

Every human being has the potential to perform deviant behavior including student. Student deviant behavior associated with aspects of criminal, anti-social and actions that are not in accordance with the values that apply on campus shows the frequency of different or not the same amount. Compared with these three aspects of student deviant behavior on campus it shows that aspects of action that do not fit with the values that apply on campus far more than criminal and anti-social. Also the student's deviant behavior of criminal aspects is less than the deviant behavior of social aspects. This shows the determination of different social controls on these three aspects of deviant behavior in the PIPS Prodi that has been done so far.

Social control is a social order that directly or indirectly exists in every social institutions, social organizations and social institutions with diverse forms. As an educational institution, Higher Education / Campus also between the one with others certainly have various ways or forms in social control. Preventive and repressive social control are two forms of collective-functional control which means that all elements of PIPS Program are based on their respective function of running social controls against students' deviant behavior either preventively or repressively.

The concept of deviant behavior gained very high attention in various scientific perspectives. This is due to deviant behavior with another perspective / perspective will give other meanings and meanings as well. Some analyze the deviant behavior from a statistical perspective whereby it can be briefly understood that the deviant behavior that occurs occurs is measured by taking into account the distance between the appearance of the action or the deviant behavior with the intent of such behavior in general. This means that it will be understood by the individual's distorted behavior by attributing the behavior's behavior to the most common behavioral aberrations, but the perspective of deviant behavior from the point of statistical analysis is taken by Becker by saying:

"Hungting with such a definition, murderers, redheads, homosexuals, and traffic violators. The mixture contains some ordinarily thought of as deviants and others who have broken no rule at all. The statistical definition of deviance, in short, is too far removed from the concern with the rulebreaking which prompts scientific study of outsiders. [15]

If it is compared with Howard S. Becker's view of the results of this study, the study finds the concept of developing a social control called collective-functional control. Collective-functional control of PIPS Prodi community has been running but the process has not been maximized and has not been integrated consistentlysustainable. If collective-functional controls are consistent and integrated, not only can the student's deviant behavior be controlled but also all elements of PIPS Prodi society ie lecturers, data abstracts, and study leaders are also controlled from deviant behavior.

Social control in every social institutions, social organizations as well as social institutions including in PIPS Prodi is influenced by several factors. The intensity of existing factors greatly affects the student's deviant behavior. The more optimal and not the factor on the existence of their respective roles and functions will determine the intensity of student deviant behavior. Thus, when all the factors of determinant social control existing in this study contribute together and show the depth and intensity of a strong commitment then the student's deviant behavior will be controlled by the opposite.

\section{CONCLUSION}

Every human being has the potential to perform deviant behavior including student. Preventive and repressive social 
control are two forms of collective-functional control which means all elements / societies of PIPS Prodi based on their function. They have social control over student deviant behavior. The collective-functional control of the PIPS Prodi community is not yet maximized, yet consistently integratedcontinuously. If all elements of the Prodi PIPS community that is the lecturers, data pengimput and leadership Prodi involved in controlling behavior deviant students will be controlled from deviant behavior.

In order for this to be realized then the existence / existence of the norms, values and rules of academic.in a campus is a reference to the campus community in creating life with regularity and harmony. Academic norms, values and rules must be clear, not multi-interpretive, nonoverlapping from the University, Faculty to Prodi levels indicate consistency. Itupula must be internally documented to make it easier for the campus community to access it.

In addition, All campus communities should have a high awareness to uphold and comply with all academic norms, values and rules without exception. In order for this to happen then law enforcement must be done consistently and decisively. This means that anyone who violates must get clear and firm sanctions. Besides, social control with all its forms is also ensured to run consistently and tiered from the level of University, Faculty until Prodi level.

While that is no less urgrnnya is needed dynamics of innovation and creativity in controlling and overcome the deviant behavior of students through social control of them. It is realized that the world of college and university students will always change according to the changing times. So adjustments should always be pursued so that no impression that neither the norms, values and academic rules or the forms of social control that have been carried out have gone a step or step compared to the dynamics of the campus and the social dynamics of the students. By that, it takes an institution within the campus that can always do research that is specifically review the problems of social control and behavior deviant consistently and sustainably.

\section{ACKNOWLEDGMENT}

Alhamdulillah. Sollallahu 'alaa Muhammad, The author realizes how much help and support from various parties so that this research can be completed. By that, the authors would like to express their deepest gratitude and appreciation to: Rector, Head of Research Institute, Head of Research Center of Makassar State University, and Dean of Faculty of Social Sciences of Makassar State University and Party of PIPS and students. From deep in the heart of the author say many thanks to all parties. Thank you for your help and support, hopefully the blessings and grace of God Always be with all of us. Amin ya Rabbal Alamin
[2] H. Li, Y. Ma, L. Meng, X. Qiao, and X. Shi, "Skill complementarities and returns to higher education: Evidence from college enrollment expansion in China," China Econ. Rev., vol. 46, pp. 10-26, 2017.

[3] R. French and P. Oreopoulos, "Behavioral barriers transitioning to college," Labour Econ., vol. 47, pp. 48-63, 2017.

[4] E. W. Dillon, "The college earnings premium and changes in college enrollment: Testing models of expectation formation," Labour Econ., vol. 49, pp. 84-94, 2017.

[5] C. Ellegaard and C. J. Medlin, "Finding good relationships intended and realized relational governance of international fine wine exchanges," J. World Bus., 2018.

[6] I. Lindh, "Entrepreneurial development and the different aspects of reflection," Int. J. Manag. Educ., vol. 15, no. 1, pp. 26-38, 2017.

[7] M. Krawczyk and M. Sylwestrzak, "Exploring the role of deliberation time in non-selfish behavior: The double response method," J. Behav. Exp. Econ., vol. 72, pp. 121-134, 2018.

[8] S. Fuller, "Chapter 3 - Information Technology as the Key to the Knowledge Revolution," in KMCI Press, S. B. T.-K. M. F. Fuller, Ed. Boston: Butterworth-Heinemann, 2002, pp. 116-195.

[9] R. A. Gordon, "Everyday life as an intelligence test: Effects of intelligence and intelligence context," Intelligence, vol. 24, no. 1, pp. 203-320, 1997.

[10] A. Harrison, R. Burress, S. Velasquez, and L. Schreiner, "Social Media Use in Academic Libraries: A Phenomenological Study," $J$. Acad. Librariansh., vol. 43, no. 3, pp. 248-256, 2017.

[11] D. Nduhura and M. Prieler, "When I chat online, I feel relaxed and work better: Exploring the use of social media in the public sector workplace in Rwanda," Telecomm. Policy, vol. 41, no. 7, pp. 708716, 2017.

[12] M. Serje, "Social relations: A critical reflection on the notion of social impacts as change," Environ. Impact Assess. Rev., vol. 65, pp. 139-146, 2017.

[13] G. D. Suttles, "Friendship as a social institution," in Friendship as a Social Institution, Routledge, 2017, pp. 95-135.

[14] P. Näykki, S. Järvelä, P. A. Kirschner, and H. Järvenoja, "Socioemotional conflict in collaborative learning-A process-oriented case study in a higher education context," Int. J. Educ. Res., vol. 68, pp. 1-14, 2014.

[15] M. Felson and M. A. Eckert, Introductory Criminology: The Study of Risky Situations. Routledge, 2017.

\section{REFERENCES}

[1] J. E. Lowry, Medical Students' Perspectives on Their Experiences as Medical Scribes. Michigan State University, 2017. 